\title{
Serological and molecular detection of Bean leaf roll and Chickpea chlorotic stunt luteoviruses in chickpea from Iran
}

\author{
Tara Hajiyusef ${ }^{2}$, Nooh Shahraeen ${ }^{1 *}$, Mojdeh Maleki $^{2}$ \\ ${ }^{1}$ Plant Virus Research Department, Iranian Research Institute of Plant Protection (IRIPP), Agricultural Research Education \\ and Extension Organization (AREEO), Tehran, Iran \\ ${ }^{2}$ Department of Plant Protection, College of Agriculture, Varamin-Pishva Branch, Islamic Azad University, Varamin, Iran
}

Vol. 57, No. 2: 136-143, 2017

DOI: 10.1515/jppr-2017-0018

Received: November 7, 2016

Accepted: May 22, 2017

*Corresponding address:

shahraeennoah@gmail.com

\begin{abstract}
Chickpea (Cicer arietinum L.) is an important legume crop and widely cultivated in northwestern provinces of Iran. During a survey in the 2015 growing season a total of 170 selected chickpea plants with general yellowing symptoms including stunting and leaf bronzing were collected. Serological Elisa and tissue blot immunoassay (TIBA) tests revealed the presence of Bean leaf roll virus (BLRV) and Chickpea chlorotic stunt virus (CpCSV) as the predominant viruses in the region. Some serologically positive samples of BLRV and CpCSV were selected and rechecked by RT-PCR. The results of amplified PCR products using a specific pair of primers towards the $C p$ gene region of the viruses were approximately 413 bp for CpCSV and 391 bp for BLRV. Results obtained from sequence comparison of BLRV (IR-F-Lor-5) isolate form two subgroups with eight other BLRV isolates from GeneBank indicating a high homology of $96 \%$ with isolates from Argentina, Germany, Tunisia, USA, Spain, and Colombia. An isolate from Norabad (Iran) (IR-Nor) had 98\% homology with HQ840727 Libyan isolate. CpCSV sequence comparison with six other GeneBank isolates indicated 98\% homology with isolates from Tunisia and Azerbaijan. The overall results of this research revealed the CPCSV and BLRV (luteoviruses) associated with the yellowing disease syndrome of chickpea crops in the surveyed region.
\end{abstract}

Key words: BLRV, CpCSV, phylogeny, serology, sequence comparison

\section{Introduction}

Chickpea (Cicer arietinum L.) is the second most important legume cultivated generally on residual soil moisture in arid and semi-arid regions of the world (Jukanti et al. 2012). Chickpea is also an important legume crop in Iran and is widely cultivated in the northwestern provinces of Lorestan, Kermanshah, West Azarbaijan, Zanjan, Arak, Eilam and Hamedan, with an estimated cultivated area of 472,000 ha in the 2013-2014 growing season (Anonymous 2013).

Several diseases caused by plant viruses have recently emerged to cause economic losses (Subbarao et al. 2015; Minicka et al. 2016). Viruses are known to infect chickpea plants worldwide, some of which cause serious economic losses (Bos et al. 1988; Najar et al. 2000; Chen et al. 2011). These viruses are genetically diverse but collectively share several features clearly distinct from other plant viruses (Smith and Barker 1999; D’Arcy et al. 2000).

Luteoviruses cause significant yield losses around the world in economically important crops such as beets, cereals, faba beans, peas, lentils, potatoes and a variety of legumes, especially chickpeas (D'Arcy et al. 2000; Abraham et al.2006). Surveys conducted in many countries in the WANA region (North and West Africa) during the last three decades (Kaiser 1972; Horn et al. 1993, 1995; El-Muadhidi et al. 2001; Makkouk and Kumari 2001; Makkouk et al. 2002) established that the most important cool legume viruses are: Faba bean necrotic yellows virus (FBNYV: genus Nanovirus; family Nanoviridae), Bean leaf roll virus (BLRV: genus Luteovirus; family Luteoviridae), Beet western yellows virus (BWYV: genus Polerovirus; family Luteoviridae), 
Soybean dwarf virus (SbDV: genus Luteovirus; family Luteoviridae) and Chickpea chlorotic stunt virus (CpCSV: genus Polerovirus; family Luteoviridae) which affect legume crops (Smith et al. 1999; D’Arcy et al. 2000; Leslie et al. 2002).

To date, five luteoviruses have been reported to infect faba bean and/or chickpea in different parts of the world (D'Arcy et al. 2005), namely BLRV (Makkouk et al. 1993), BWYV (Fortass et al. 1997), SbDV (Tamada et al. 1977), Pea enation mosaic virus-1 (PEMV-1) (Demler et al. 1995), and Chickpea stunt disease associated virus (CpSDaV). The latter has been reported only in India and is closely related to, but distinct from, BWYV (Naidu et al. 1997). During a survey of chickpea crops in western provinces of Iran in July 2009 (Bananej et al. 2010), leaf samples from yellow and stunted plants were collected from fields in the provinces of Kermanshah and Lorestan. Symptoms suggested infections by luteoviruses, such as BWYV and CpCSV, a virus first described in Ethiopia (Abraham et al. 2006) and West Asia and North Africa (Abraham et al. 2009).

Chickpea plants showing symptoms suggestive of viral infection such as leaf rolling, yellowing, reduction in overall plant growth, dwarf stem, foliar bronzing and stunting, were observed in Lorestan, Kermanshah, Hamedan and West Azerbaijan regions of Iran. Serological tests showed the presence of four different viruses, BLRV, BWYV, CpCSV and SbDV, in these regions (Shahraeen et al. 2016).

There were reports of chickpea infection by several viral diseases in Iran (Kaiser 1972; Kaiser and Danesh 1972; Makkouk et al. 2002; Hydari et al. 2011; Shahraeen et al. 2012, 2016). The aim of this study was to apply a rapid reverse transcription-polymerase chain reaction (RT-PCR) based method for detection and differentiation of BLRV and CPCSV Iranian strains, the most frequent occurring luteoviruses in cool season legume crops (Shahraeen et al. 2016).

\section{Materials and Methods}

\section{Source of materials}

Naturally infected chickpea samples were collected from five locations in Lorestan, 12 locations in Kermanshah and two locations in Hamedan, Iran (Makkouk et al.2003). Therewere three farms per location and 170 plants were collected from each location. The luteovirus-like isolates were obtained from chickpea plants showing identical symptoms suggestive of viral infection such as foliar yellowing, chlorosis or leaf reddening, stunting, growth reduction, phloem browning, and leaf narrowing.

\section{Identification of the isolated viruses}

All collected samples were tested for luteovirus infection using tissue-blot immunoassay (TIBA), triple antibody sandwich (TAS) and antigen coated plate (ACP)-indirect Elisa procedure using a battery of rabbit poly and monoclonal antibodies for CpCSV, BLRV(5G4), BLRV(6G4), and polyclonal antisera for BWYV and SbDV (Kumari et al. 2008; Shahraeen et al. 2016). To identify the BLRV and CpCSV-luteovirus affecting chickpea in farmers' fields, infected samples that gave a positive reaction to the recent antibodies were tested by RT-PCR using specific primers as described (Table 1).

\section{RNA extraction}

Fifteen chickpea samples that reacted serologically positive with BLRV and CpCSV antibodies were selected for further testing by RT-PCR. Total RNA was extracted from 50 to $100 \mathrm{mg}$ virus infected young leaves and stems by using RNX-Plus solution kit (Sinaclone, Iran, Cat No. RN7713C). Purified RNA was stored as a solution in water at $-80^{\circ} \mathrm{C}$.

Table 1. Specific primers used in this study and polymerase chain reaction (PCR) thermocycling conditions

\begin{tabular}{|c|c|c|c|c|}
\hline Sequence & Primers & PCR profile & Amplicon size [bp] & Reference \\
\hline $\begin{array}{l}\text { BLRV-3 } \\
\text { BLRV-5 }\end{array}$ & $\begin{array}{l}\text { 5'-TCCAGCAATCTTGGCATCTC-3' } \\
\text { 5'-GAAGATCAAGCCAGGTTCA-3' }\end{array}$ & $\left.\begin{array}{l}95^{\circ} \mathrm{C}, 2 \mathrm{~min} \\
95^{\circ} \mathrm{C}, 30 \mathrm{~s} \\
56^{\circ} \mathrm{C}, 30 \mathrm{~s} \\
72^{\circ} \mathrm{C}, 30 \mathrm{~s}\end{array}\right\} \times 40$ & 391 & Oritz et al. 2005 \\
\hline $\begin{array}{l}\text { CpCSV-F } \\
\text { CpCSV-R }\end{array}$ & $\begin{array}{l}\text { 5'-TAGGCGTACTGTTCAGCGGG-3' } \\
\text { 5'-TCCTTTGTCCATTCGAGGTGA-3' }\end{array}$ & $\left.\begin{array}{l}95^{\circ} \mathrm{C}, 2 \mathrm{~min} \\
95^{\circ} \mathrm{C}, 30 \mathrm{~s} \\
53^{\circ} \mathrm{C}, 30 \mathrm{~s} \\
72^{\circ} \mathrm{C}, 30 \mathrm{~s}\end{array}\right\} \times 30$ & 413 & Abraham et al. 2006 \\
\hline
\end{tabular}




\section{Reverse transcription - polymerase chain reaction ( $R T-P C R)$}

Reverse transcription PCR was performed as described for both viruses (BLRV and CpCSV) (Oritz et al. 2005; Abraham 2005; Abraham et al. 2006). Seven $\mu$ lotal RNA, $2 \mu \mathrm{l}$ reverse primer (Sinaclon, Iran) and $3.5 \mu \mathrm{l}$ water, were heated at $70^{\circ} \mathrm{C}$ for $5 \mathrm{~min}$. The reaction was cooled on ice for $2 \mathrm{~min}$ and the following reagents added: $4 \mu \mathrm{l}$ 5X first-strand buffer, $2 \mu \mathrm{dNTP}$ (Fermentase, Germany), $0.5 \mu \mathrm{l}$ ribonuclease inhibitor and $1 \mu \mathrm{l}$ reverse transcriptase enzyme (Sinaclone, Iran). The reaction was incubated at $37^{\circ} \mathrm{C}$ for $5 \mathrm{~min}$, then $42^{\circ} \mathrm{C}$ for $60 \mathrm{~min}$ before being inactivated at $70^{\circ} \mathrm{C}$ for $10 \mathrm{~min}$. PCR reactions using generic luteovirus (BLRV and CpCSV) primers (Table 1) consisted of $1 \mu \mathrm{l} \mathrm{MgCl}, 1 \mu \mathrm{l}$ forward primer, $1 \mu \mathrm{l}$ reverse primer and $12.5 \mu \mathrm{l}$ Red Taq (mini kit, Pishgam BC, Iran). Thermocycling conditions were as follows in two different procedures ( Table 1). The presence and identity of viruses in CDNA from infected plant samples were checked by PCR with specific primers as described (Table 1). PCR reactions were replicated at least five times. All PCR products were analyzed in 1-3\% agarose gels (Kumari et al. 2008; Chomic et al. 2010).

\section{Results}

The collected samples which showed positive reactions to generic luteovirus monoclonal antibodies (BLRV-5G4 and 6G4) (DSMZ-Germany) and subsequently polyclonal antibody specific to BLRV were used in Elisa tests. When 10 selected samples were tested by RT-PCR using two specific primer pairs (Table 1), chickpea samples numbers 1, 5 and 6 (Nour Abad, Aleshtar and Khoram Abad regions) yielded amplicons of 391 bp product with BLRV primers (Fig. 1). Furthermore, only one sample, number 20 (Sar Aroud region), yielded amplicons of 413-bp product with CpCSV primers (Fig. 2). No amplification was observed from healthy plant extracts.

Two BLRV samples (Nos. 1 and 5) and one CpCSV (No. 20) were sent to Faza Pajoh company (Iran) for sequencing. The target sequences were Blast in Gen Bank and compared, respectively, with 7 BLRV and 6 CpCSV of $C p$ gene sequences of the virus strains registered in Gen Bank (Table 2). Potato leaf roll virus isolate Cole-25 (Accession No. HQ171923) was selected as an out group member. Sequence alignment was performed using the Clustal X, Ver. 1.83 program and the phylogenetic tree was drawn using the Mega 4 program (Thompson et al. 1994).

\section{Coat protein gene amplification, sequencing and sequence analysis}

In molecular assays, approximately $\sim 391$ bp products were amplified using specific primers for BLRV and 413 bp products for CpCSV (Table 1). Annealing temperatures for a primer pair were $56^{\circ} \mathrm{C}$ for BLRV and $53^{\circ} \mathrm{C}$ for CpCSV. Two nucleotide sequences for BLRV (Figs. 1, 2) and one for CpCSV (Figs. 3, 4) species comprising partial $C p$ gene were obtained after RT-PCR amplification reactions with the appropriate primers. Each of the nucleotide sequences of the CpCSV and BLRV Iranian isolates was compared with corresponding $C p$

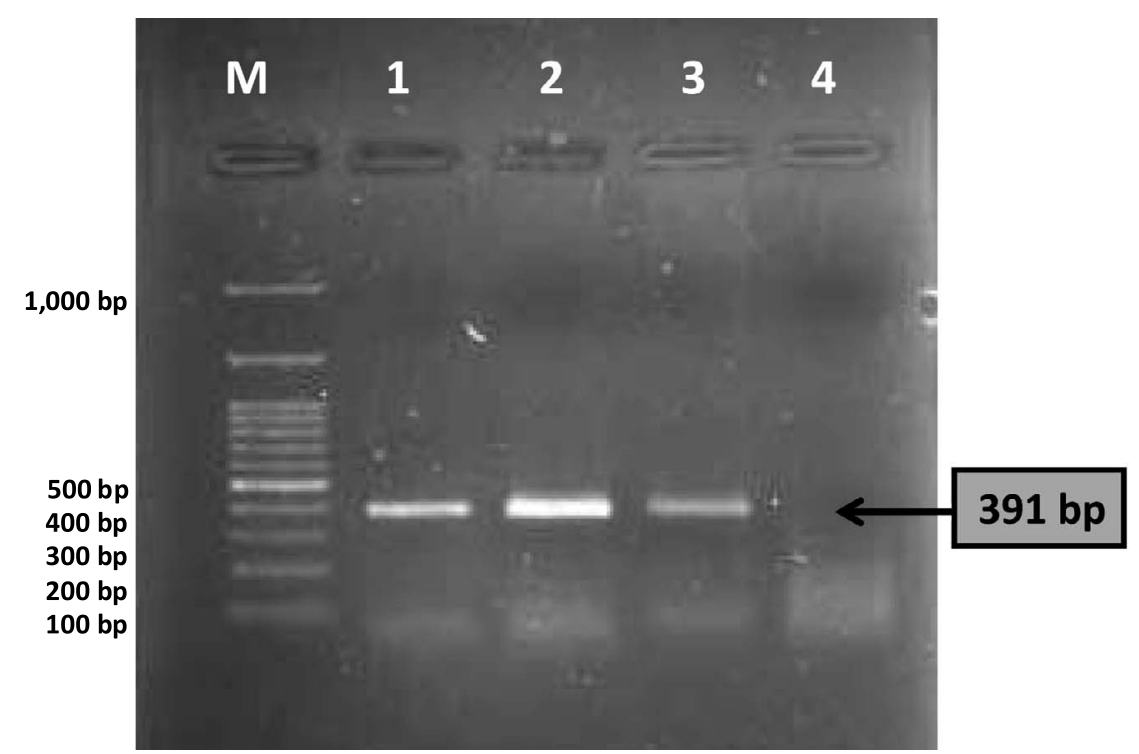

Fig. 1. $P C R$ amplification products using specific BLRV primers: lane $M-G e n e R u l e r^{\mathrm{TM}} 100 \mathrm{bp}$ DNA ladder (Fermentas), lane 1 - BLRV samples 1 (Nour Abad, Lorestan), lane 2 - BLRV sample 5 (Aleshtar, Lorestan), lane 3 - BLRV sample 6 (Takane, Lorestan), lane 4 - negative (water). PCR products were analysed in $3 \%$ agarose gel 


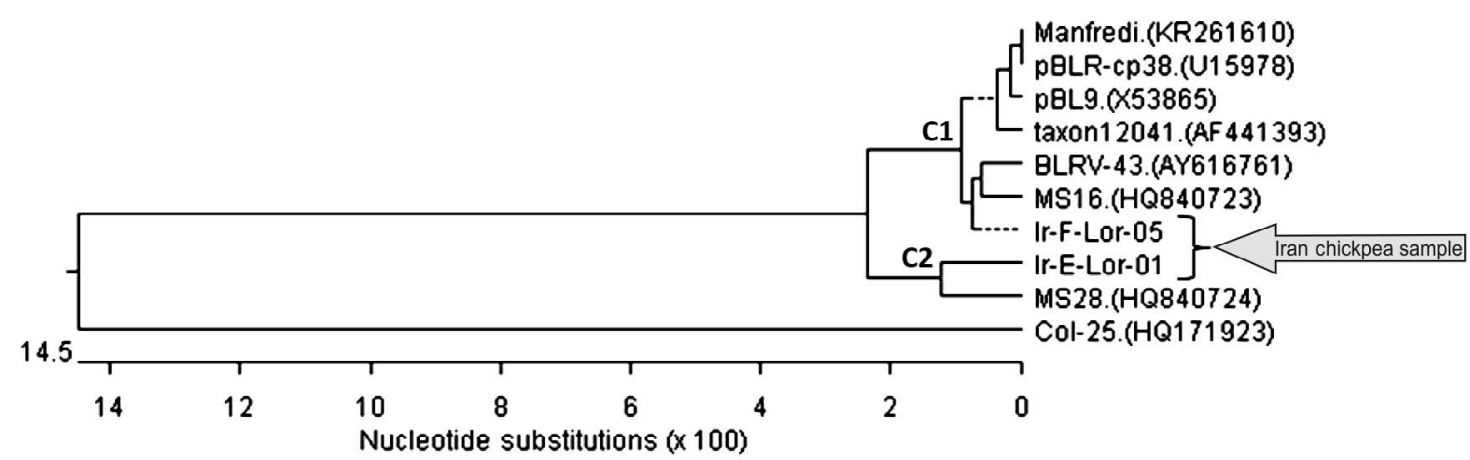

Fig. 2. Phylogenetic tree reconstructed based on comparison sequences isolate of chickpea BLRV and seven different isolates. C1 - cluster 1, C2 - cluster 2

gene sequences of a few representative isolates from other parts of the world (Table 2). Blast algorithm (Altschul et al. 1997) and grouping according to a specified isolate were used. Phylogenetic analysis (Megalighn software) based on partial nucleotide sequences (Fig. 2) for BLRV revealed two main clusters. The first cluster contained two subgroups which included isolates from the Alshtar-Lorestan region (IR-F-lor-05and) besides Tunisian and Spanish isolates. The second BLRV sub-group consisted of an isolate from Noorabad (Lorestan-IR-E-Lor-01) which grouped with the Libyan isolate. CpCSV sequence analysis formed one cluster with two subgroups (Fig. 3). CpCSV Kermanshah isolate from the present study was placed in the first subgroup along with isolates from Tunesia and Azerbaijan. The previously reported CpCSV Iranian isolates (Bananej et al. 2010) were placed in the second subgroup along with the Syrian isolate. For both viruses, Potato leaf roll virus-isolate ( $\mathrm{Col} 25)$ was used as an out group sample member (Table 2).

Sequence comparison of the studied isolates of BLRV with similar isolates in NCBI, using Meg Align software, revealed the highest identity (99.4\%) between Ir-F-Lor-05 isolate and Manfredi (Acc.No-KR261610), pBLR-cp38(Acc.No-U15978), toxon-12041(Acc.No-AF441393) and BLRV-43(Acc.No-AY616761) from Argentina, Spain, USA and Spain, respectively. The lowest similarity (95.2\%) was observed between one

Table 2. Bean leaf roll virus (BLRV) and Chickpea stunt disease associated virus (CpCSV) isolate comparison

\begin{tabular}{|c|c|c|c|c|}
\hline Isolates & Host & Country & $\begin{array}{c}\text { NCBI GenBank } \\
\text { Accession Number }\end{array}$ & $\begin{array}{c}\text { Percentage similarity } \\
\text { with chickpea sample } \\
\text { from Iran }\end{array}$ \\
\hline \multicolumn{5}{|l|}{ BLRV-Isolates } \\
\hline MS28 & Vicia faba $\mathrm{L}$. & Libya & HQ840724 & 98 \\
\hline pBL9 & - & Germany & X53865 & 96 \\
\hline Manfredi & Medicago sativa $\mathrm{L}$. & Argentina & KR261610 & 96 \\
\hline MS16 & Cicer arietinum L. & Tunisia & HQ840723 & 96 \\
\hline taxon 12041 & - & USA & AF441393 & 96 \\
\hline BLRV-43 & V. faba & Spain & AY616761 & 96 \\
\hline pBLR-cp38 & - & USA & U15978 & 96 \\
\hline PLRV-Col-25 & Solanum betaceum Cav. & Colombia & HQ171923 & - \\
\hline \multicolumn{5}{|c|}{ CpCSV-Isolates } \\
\hline Az296-07 & Legumes & Azerbaijan & HQ199305 & 98 \\
\hline Ir-ch-Ker-31 & C. arietinum & Iran & GU930838 & 98 \\
\hline Ir-ch-Lor-25 & C. arietinum & Iran & GU930837 & 98 \\
\hline Az Cp50-07 & Legumes & Azerbaijan & HQ180354 & 98 \\
\hline TuC215-201 & Legumes & Tunisia & HQ199307 & 98 \\
\hline 16Sy-fb1-03 & North Africa and West Asia & Syria & EU541270 & 98 \\
\hline PLRV-Col-25 & S. betaceum & Colombia & HQ171923 & - \\
\hline
\end{tabular}




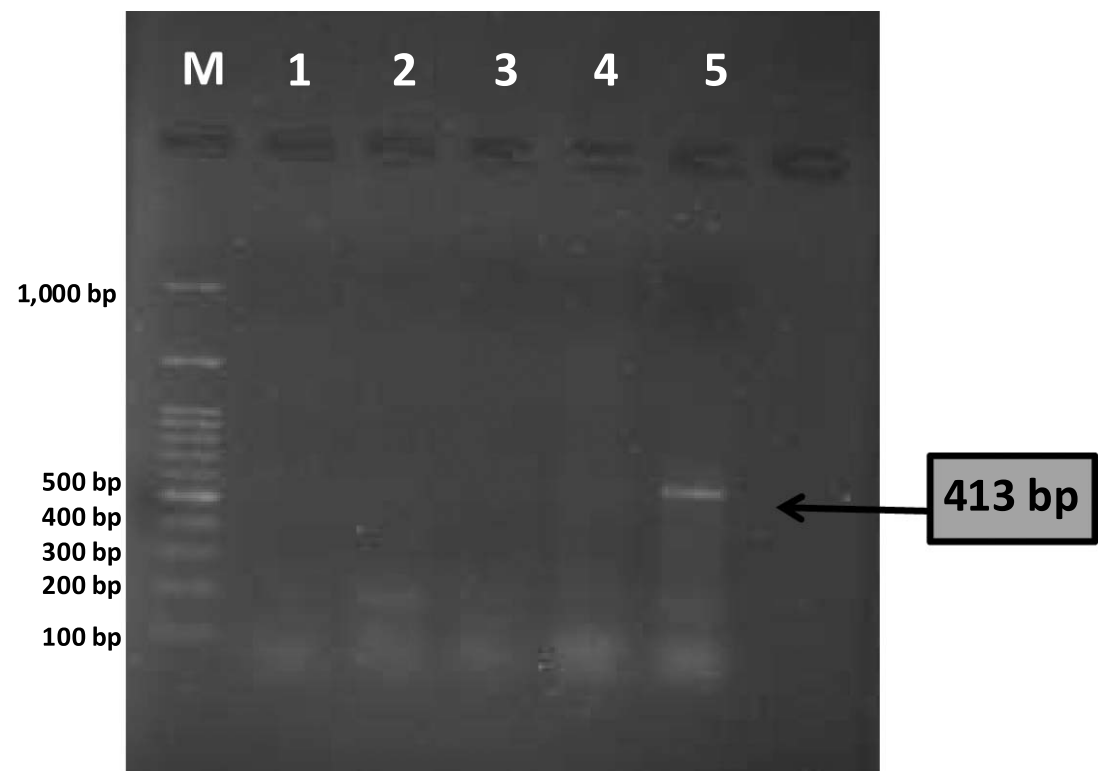

Fig. 3. $P C R$ amplification products using specific CpCSV primers: lane $M-$ GeneRuler $^{\mathrm{TM}}$ 100 bp DNA Ladder (Fermentas), lane 1 - negative (water), lane 2 - CpCSV sample 5 (Aleshtar, Lorestan), lane 3 - CpCSV sample 14 (Ravansar, Kermanshah), lane 4 - CpCSV sample 27 (Harsin2, Kermanshah), lane 5 - CpCSV sample 20 (Sar Aroud, Kermanshah). Only sample 20 (lane 5) was positive to CpCSV primer. PCR products were analysed in $3 \%$ agarose gel

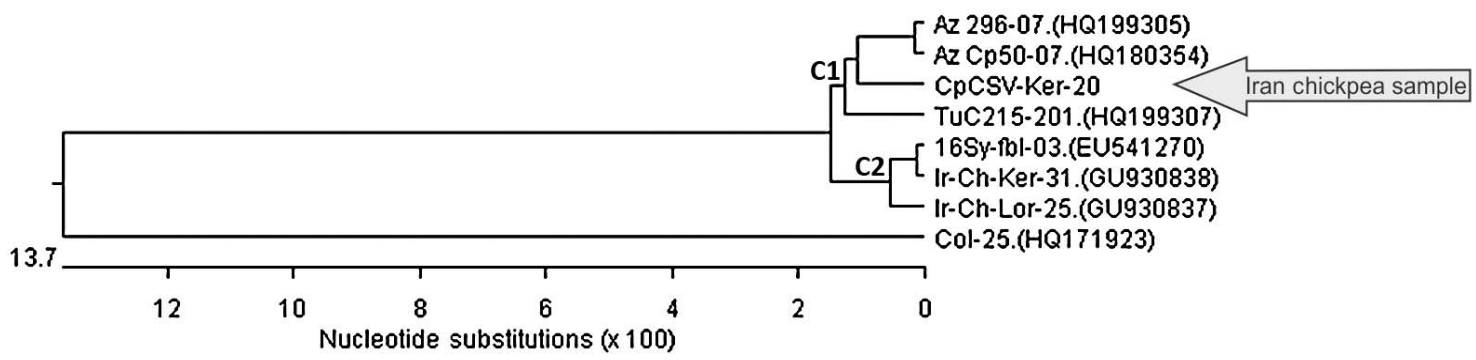

Fig. 4. Phylogenetic tree reconstructed based on comparison sequences isolate of chickpea CpCSV and seven different isolates. C1 - cluster 1, C2 - cluster 2

of the studied isolates (Ir-Lor-05) and MS28(Acc.No-HQ840724) isolate from Libya whereas the similarity between the two studied isolates was $96.4 \%$ (Table 3 ).

In the case of CpCSV the highest identity was $97.8 \%$ between the studied isolate and Az296-07(Acc.No-HQ199305) isolate from Azerbaijan and Ir-Ch-Lor-25(Acc.No-GU930837) which was previously reported in Iran. The lowest similarity was $97.3 \%$ between the studied isolate and 16Sy-fbl-03(Acc.No-EU541270) (Table 4). There are different reports of similarities in sequence homology of CpCSV Iranian isolates (Bananej et al. 2010; Shahraeen et al. 2016). Based on the phylogram, it is clear that clustering of the present luteovirus isolates with other strains/isolates was not based on host or geographic region. Evidence for recombination has not been evaluated and there is a need to determine if there is any recombination.

\section{Discussion}

Several viruses are known to infect chickpea worldwide, some of which cause serious economic losses (Bos et al. 1988; Horn et al. 1993, 1995; El-Muadhidi et al. 2001; Makkouk et al. 2002; Chen et al. 2011). There have been reports of chickpea infection by several viral diseases in Iran causing symptoms such as foliar yellowing, chlorosis or leaf reddening, stunting, growth reduction, phloem browning, and leaf narrowing (Kaiser and Danesh 1972; Makkouk et al. 2002; Bananej et al. 2010; Hydari et al. 2011; Shahraeen et al. 2012, 2016).

The present study revealed some serological and molecular properties of BLRV and CpCSV (luteoviruses) infecting chickpea in some parts of Iran. Our 
Table 3. Percent similarity between analyzed Bean leaf roll virus (BLRV) strains

\begin{tabular}{|c|c|c|c|c|c|c|c|c|c|c|c|}
\hline & \multicolumn{11}{|c|}{ Percent Identity } \\
\hline & 1 & 2 & 3 & 4 & 5 & 6 & 7 & 8 & 9 & 10 & \\
\hline \multirow{11}{*}{ 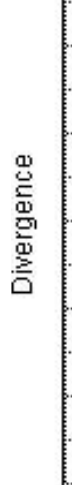 } & & 72.5 & 95.8 & 99.4 & 98.8 & 98.8 & 94.6 & 98.5 & 98.8 & 98.8 & 1 \\
\hline & 28.1 & & 71.3 & 72.5 & 72.5 & 70.8 & 70.2 & 72.5 & 72.5 & 72.5 & 2 \\
\hline & 4.0 & 28.9 & & 96.4 & 95.8 & 95.8 & 97.6 & 96.1 & 95.8 & 95.8 & 3 \\
\hline & 0.6 & 28.1 & 3.4 & & 99.4 & 98.8 & 95.2 & 99.1 & 99.4 & 99.4 & 4 \\
\hline & 1.2 & 28.1 & 4.0 & 0.6 & & 98.2 & 94.6 & 99.7 & 100.0 & 99.4 & 5 \\
\hline & 1.2 & 29.8 & 4.0 & 1.2 & 1.8 & & 95.8 & 97.9 & 98.2 & 98.2 & 6 \\
\hline & 5.3 & 29.8 & 2.4 & 4.6 & 5.3 & 4.0 & & 94.9 & 94.6 & 94.6 & 7 \\
\hline & 1.5 & 28.1 & 3.7 & 0.9 & 0.3 & 2.1 & 5.0 & & 99.7 & 99.1 & 8 \\
\hline & 1.2 & 28.1 & 4.0 & 0.6 & 0.0 & 1.8 & 5.3 & 0.3 & & 99.4 & 9 \\
\hline & 1.2 & 28.1 & 4.0 & 0.6 & 0.6 & 1.8 & 5.3 & 0.9 & 0.6 & & 10 \\
\hline & 1 & 2 & 3 & 4 & 5 & 6 & 7 & 8 & 9 & 10 & \\
\hline
\end{tabular}

\author{
BLRV-43.(AY616761) \\ Col-25.(HQ171923) \\ Ir-E-Lor-01 \\ Ir-F-Lor-05 \\ Manfredi.(KR261610) \\ MS16.(HQ840723) \\ MS28.( $\mathrm{HQ840724)}$ \\ pBL9. $(\times 53865)$ \\ pBLR-cp38.(U15978) \\ taxon12041.(AF441393)
}

Table 4. Percent similarity between analyzed Chickpea chlorotic stunt virus (CpCSV) strains

\begin{tabular}{|c|c|c|c|c|c|c|c|c|c|c|}
\hline \multicolumn{11}{|c|}{ Percent Identity } \\
\hline \multirow{10}{*}{$\begin{array}{l}1 \\
2 \\
3 \\
4 \\
5 \\
6 \\
7 \\
8\end{array}$} & 1 & 2 & 3 & 4 & 5 & 6 & 7 & 8 & & \multirow{2}{*}{ 16Sy-fbl-03.(EU541270) } \\
\hline & & 96.9 & 96.6 & 74.4 & 97.3 & 99.8 & 99.0 & 96.4 & 1 & \\
\hline & 3.0 & & 99.8 & 73.7 & 97.8 & 96.6 & 96.9 & 97.6 & 2 & Az 296-07.(HQ199305) \\
\hline & 3.2 & 0.2 & & 73.3 & 97.6 & 96.4 & 96.6 & 97.3 & 3 & $\mathrm{Az} C p 50-07 .(\mathrm{HQ180354)}$ \\
\hline & 26.9 & 28.0 & 28.6 & & 73.3 & 74.0 & 74.8 & 74.0 & 4 & $\mathrm{Col}-25 .(\mathrm{HQ171923)}$ \\
\hline & 2.5 & 2.0 & 2.2 & 28.0 & & 97.6 & 97.8 & 97.6 & 5 & Cpcsv-Ker-20 \\
\hline & 0.2 & 3.2 & 3.5 & 27.5 & 2.2 & & 98.8 & 96.1 & 6 & Ir-Ch-Ker-31 (GU930838) \\
\hline & 1.0 & 3.0 & 3.2 & 26.4 & 2.0 & 1.2 & & 96.6 & 7 & Ir-Ch-Lor-25.(GU930837) \\
\hline & 3.5 & 2.5 & 2.7 & 27.5 & 2.5 & 3.7 & 3.5 & & 8 & TuC215-201.(HQ199307) \\
\hline & 1 & 2 & 3 & 4 & 5 & 6 & 7 & 8 & & \\
\hline
\end{tabular}

findings from sequence comparisons and phylogeny suggest that these two luteoviruses may have been introduced and/or established in the region through diverse agricultural cropping systems, specific vector population activity, susceptible hosts/variety and changes in climate.

Further study is required to investigate the evolution of cool season food legume, (chickpea and lentil) luteovirus like populations in Iran. In this study and in Elisa tests more plant samples showing yellowing symptoms react with BLRV-6G4 batch of monoclonal antibodies than 5G4(DSMZ-Germany) (Shahraeen et al. 2016). This suggests that there is a unique epitope to a group of isolates and hence can be used for discrimination of a specific group of BLRV isolates. These limited data suggest that there may be a genetically, biologically and geographically distinct strain group (population) of BLRV and CPCSV infecting cool season food legumes (chickpea) in Iran which require thorough investigation.

Prevalence and variations according to the geographical origin have been reported for other plant viruses from Iran (Shahraeen et al. 2002, 2005; Alimoradian et al. 2016).
Beet western yellows virus and Soybean dwarf virus were also detected in our samplings and serological assays but they are not described in this paper (Shahraeen, unpublished). These two viruses with their detection in samples collected as early as 2002, 2001 (Makkouk et al. 2002) in the northern part of the country indicate that the BLRV and CpCSV (luteoviruses), from the cool season food legumes, are not recent (Shahraeen et al. 2016). They have probably been infecting the legume plants for decades but remained undetected or were wrongly identified as a different virus of legumes possibly due to the lack of appropriate diagnostic tools or cross-reacting antibodies. Further study on both the incidence and variability of CPCSV and BLRV in the country or in a region is required for determining the economic importance.

\section{Acknowledgements}

We would like to thank Miss Tabassom Ghotbi (IRIPP-Plant Virus Department) and Dr. Mehdi Shirazi (Azad University Tehran) for their help during this study. 


\section{References}

Abraham A. 2005. Characterization and genome organization of new luteoviruses and nanoviruses infecting cool season food legumes. Chapter 5. Ph.D. thesis. Faculty of Agriculture Sciences, George-August University, Göttingen, Germany, 147 pp.

Abraham A.D., Memzel W., Varrelmann M., Vetten H.J. 2009. Molecular, serological and biological variation among Chickpea chlorotic stunt virus isolates from five countries of North Africa and West Asia. Archives of Virology 154 (5): 791799. DOI: 10.1007/s00705-009-0374-0

Abraham A.D., Menzel W., Lesemann D.E., Varrelmann M., Vetten H.H. 2006. Chickpea chlorotic stunt virus: A new Polerovirus infecting cool-Season food legumes in Ethiopia. Phytopathology 96 (5): 437-446. DOI: 10.1094/PHYTO$-96-0437$

Altschul S.F., Madden T.L., Schäffer A., Zhang J., Zhang Z., Miller W., Lipman D.J. 1997. Gapped Blast and PSI-Blast: a new generation of protein database search programs. Nucleic Acids Research 25 (17): 3389-3402.

Alimoradian M., Rakhshandehroo F., Shams-bakhsh M. 2016. Prevalence and phylogenetic analysis of fig mosaic virus and fig badnavirus- 1 in Iran. Journal of Plant Protection Research 56 (2): 122-128. DOI: 10.1515/jppr-2016-0019

Anonymous 2013. Cultivated Crop Production Statistics. Office of planning and economic studies, Ministry of Agriculture, Islamic Republic of Iran, 212 pp.

Bananej K., Vahdat A., Menzel W., Vetten H.J. 2010. Serological and molecular identification of Chickpea chlorotic stunt virus from chickpea in Iran. Plant Disease 94 (6): 788. DOI: 10.1094/PDIS-94-6-0788C

Bos L., Hampton R.O., Makkouk K.M. 1988. Viruses and virus diseases of pea, lentil, faba bean and chickpea. p. 591-615. In: "World Crops: Cool Season Food Legumes" (R.J. Summerfield, ed.). Kluwer Academic Publishers, Dordrecht, The Netherlands, $1179 \mathrm{pp}$.

Chen W., Sharma H.C., Muehlbauer F.J. 2011. Compendium of Chickpea and Lentil Viruses Diseases. American Phytopathological Society (APS Press), St. Paul, USA, 160 pp.

Chomic A., Pearson M.N., Clover G.R.G., Farreyrol K., Saul D. 2010. A generic RT-PCR assay for the detection of Luteoviridae. Plant Pathology 59 (3): 429-442. DOI: 10.1111/ j.1365-3059.2010.02282.x

D’Arcy C.J., Domier L.L., Mayo M.A. 2000. Family Luteoviridae. p. 775-784. In: "Virus Taxonomy: Seventh Report of the International Committee on Taxonomy of Viruses" (M.H.V. Van Regenmortel, C.M. Fauquet, D.H.L. Bishop, L.E.B. Carstens, M.A. Mayo, D. McGeoch, J.C.R., Pringle, R.B. Wickner, eds.). Academic Press, San Diego, $1162 \mathrm{pp}$.

D’Arcy C.J., Domier L.L. 2005. Luteoviridae. p. 343-352. In: "Virus Taxonomy. Eight Report of the International Committee on Taxonomy of Viruses." (C.M. Faugnet, M.A. Mayo, J. Maniloff, U. Desselberger, L.A. Ball, eds.). Elsevier Academic Press, London, UK, 1153 pp.

Demler S.A., De Zoeten G.A., Adams G., Harris K.F. 1995. Pea enation mosaic virus: Properties, and aphid transmission. p. 303-344. In: "The Plant Viruses 5: Polyhedral Virions and Bipartite Genomes" (B.D. Harrison, A.F. Murant, eds.). Plenum Press, New York and London, 357 pp.

Domier L.L., McCoppin N.K., Larsen R.C., D’Arcy C.J. 2002. Nucleotide sequence shows that Bean leaf roll virus has a Luteovirus-like genome organization. Journal of General Virology 83: 1791-1798. DOI: 10.1099/0022-1317-83-7$-1791$

El-Muadhidi M.A., Makkouk K.M., Kumari S.G., Jerjess M., Murad S.S., Mustafa R.R., Tarik F. 2001. Survey for legume and cereal viruses in Iraq. Phytopathologia Mediterranea 40 (3): 224-233.

Fortass M.F., van der Wilk F., van den Heuvel J.F.J.M., Goldbach R.W. 1997. Molecular evidence for the occurrence of Beet western yellows virus on chickpea in Morocco. European Journal of Plant Pathology 103 (5): 481-484. DOI: 10.1023/ A:1008687629522

Horn N.M., Reddy S.V., Roberts I.M., Reddy D.V.R. 1993. Chickpea chlorotic dwarf virus, a new leafhopper-transmitted geminivirus of chickpea in India. Annals of Applied Biology 122 (3): 467-479. DOI: 10.1111/j.1744-7348.1993. tb04050.x

Horn N.M., Makkouk K.M., Kumari S.G., van den Heuvel J.F.J.M., Reddy D.V.R. 1995. Survey of chickpea (Cicer arietinum L.) for chickpea stunt disease and associated viruses in Syria, Turkey and Lebanon. Phytopathologia Mediterranea 34: 192-198.

Hydari F., Shahraeen N., Maleki M. 2011. Biological, serological and molecular identification of Cucumber mosaic virus from chickpea fields in Kermanshah province. Iranian Journal of Applied Plant Protection 3: 211-221.

Jukanti A.K., Gaur P.M., Gowda C.L.L., Chibbar R.N. 2012. Nutritional quality and health benefits of chickpea (Cicer arietinum L.): a review. British Journal of Nutrition 108: 11-26. DOI:10.1017/S0007114512000797

Kaiser W.J. 1972. Diseases of food legumes caused by Pea leaf roll virus in Iran. FAO Plant Protection Bulletin 20 (6): 127-133.

Kaiser W.J., Danesh D. 1972. Etiology of virus induced wilt of Cicer arietinum. Phytopathology 61 (5): 453-457.

Kumari S.G., Makkouk K.M., Loh M.H., Negassi K., Tsegay S., Kidane R., Kibret A., Tesfatsion Y. 2008. Viral disease affecting chickpea crops in Eritrea. Phytopathologia Mediterranea 47: 42-49.

Makkouk K.M., Kumari S.G. 2001. First record of Beet western yellows virus, Chickpea chlorotic dwarf virus and Faba bean necrotic yellows virus affecting faba bean (Vicia faba) crops in Iraq. New diseases reports. Plant Pathology 50 (6): 793. DOI: 10.1046/j.1365-3059.2001.00616.x

Makkouk K.M., Hsu H.T., Kumari S.G. 1993. Detection of three plant viruses by dot-blot and tissue-blot immunoassays using chemiluminescent and chromogenic substrates. Journal of Phytopathology 139 (2): 97-102. DOI: 10.1111/j.1439-0434.1993.tb01405.x

Makkouk K.M., Kumari S.G., Shahraeen N., Fazlali Y., Farzadfar Sh., Ghotbi T., Mansouri A. 2002. Identification and seasonal variation of viral diseases of chickpea and lentil in Iran. Journal of Plant Disease and Protection 110 (2): $157-169$.

Minicka J., Hasiów-Jaroszewska B., Borodynko N., Pospieszny H., Hanssen I.M. 2016. Rapid evolutionary dynamics of the Pepino mosaic virus - status and future perspectives. Journal of Plant Protection Research 56 (4): 337-345. DOI: https://doi.org/10.1515/jppr-2016-0054

Najar A., Makkouk K.M., Boudhir H., Kumari S.G., Zarouk R., Bessai R., Othman F.B. 2000. Viral diseases of cultivated legume and cereal crops in Tunisia. Phytopathologia Mediterranea 39: 423-432.

Naidu R.A., Mayo M.A., Reddy S.V., Jolly C.A., Torrance L. 1997. Diversity of coat proteins among luteoviruses associated with chickpea stunt disease in India. Annals of Applied Biology 130 (1): 37-47. DOI: 10.1111/j.1744-7348.1997. tb05781.x

Oritz V., Castro S., Romero J. 2005. Optimization of RT-PCR for the detection of Bean leafroll virus in plant hosts and insect vectors. Phytopathology 153 (2): 68-72. DOI: 10.1111/ j.1439-0434.2004.00929.x

Shahraeen N., Azadbakht N., Younessi H. 2012. Reports on food legume virus diseases in Iran, evaluation of control measures. In: Abstracts of the 4th Iranian Pulses Crop Symposium. Arak, Iran, 8-9 February 2012, 157 pp.

Shahraeen N., Ghotbi T., Haji Yousef T., Azadbakht N., Bananej K. 2016. An overview of viral disease on chickpea and impact on chickpea production in Iran. International Journal of Current Research and Academic Review 4 (4): 98-109. DOI: $10.20546 /$ ijcrar.2016.404.012 
Shahraeen N., Ghotbi T., Mehraban A.H. 2002. Occurrence of Impatiens necrotic spot virus in ornamentals in Mahallat and Tehran provinces in Iran. Plant Disease 86 (6): 694. DOI: 10.1094/PDIS.2002.86.6.694A

Shahraeen N., Ghotbi T., Dezaji A.E., Sahandi A. 2005. A survey of viruses affecting French bean (Phaseolus vulgaris) in Iran includes a first report of Southern bean mosaic and Bean pod mottle virus. Plant Disease 89 (9): 1012. DOI: 10.1094/PD$-89-1012 \mathrm{~B}$

Smith H.G., Barker H. 1999. The Luteoviridae. CABI Publishing, Wallingford, UK, $320 \mathrm{pp}$.
Subbarao K.V., Sundin G.W., Klosterman S.T. 2015. Focus issue article on emerging and re-emerging plant diseases. Phytopathology 105 (7): 852-854.

Tamada T., Kojima M. 1977. Soybean dwarf virus. No. 179. In: "Descriptions of Plant Viruses". Commonwealth Mycological Institute/Association of Applied Biologist, Kew, UK, 4 pp.

Thompson J.D., Higgins D.G., Gibson T.J. 1994. CLUSTAL W: improving the sensitivity of progressive multiple sequence alignment through sequence weighting, position-specific gap penalties and weight matrix choice. Nucleic Acids Research 22 (22): 4673-4680. 